\title{
Current Ethical Issues in Teacher Education: A Critical Analysis on Pre-Service and In-service Emerging Teachers
}

\author{
Rasmi Ranjan Puhan ${ }^{1, *}$, Lakshmipriya Malla ${ }^{1}$, Santosh Kumar Behera ${ }^{2}$ \\ ${ }^{1}$ Assistant Professor in Education, KIIT University (KISS), Bhubaneswar, Odisha, INDIA \\ ${ }^{2}$ Assistant Professor, Department of Education, Sidho-Kanho-Birsha University, Purulia, West Bengal, INDIA \\ *Corresponding author: rasmi.lakshmi@gmail.com
}

Received September 11, 2014; Revised November 20, 2014; Accepted December 10, 2014

\begin{abstract}
The paper intends to examine the current professional ethics, its problems and teacher taught relationship in the field of teacher education as well as how they described negotiated relationship boundaries. This study conducted in a B. Ed college under Indra Prasta University that Ram Chandra Institute of Education and Technology and in-service students of Indira Gandhi National Open University (IGNOU), and designed to document examples of ethical dilemmas faced by pre-service and practicing teachers. Also aim to explore pre-service teachers' perceptions on ethical education and to examine the $\mathrm{B}$. Ed course curriculum for ethics subjects across the one-year and two year degree course. Results highlight a need for teacher training courses to include ethical philosophy subject, at the same time a code of ethics for teaching profession. This re presents a sustainable way to support professional practice and enhance teacher quality, by preparing and equipping teachers with techniques to explore and teach complex ethical issues in the classroom and ultimately it will help the teacher to create a conducive environment within the institution which is needed for best learning.
\end{abstract}

Keywords: professional ethics, teacher education, emerging teachers, vulnerable, myriad, pre-service and inservice, IGNOU

Cite This Article: Rasmi Ranjan Puhan, Lakshmipriya Malla, and Santosh Kumar Behera, "Current Ethical Issues in Teacher Education: A Critical Analysis on Pre-Service and In-service Emerging Teachers.” American Journal of Educational Research, vol. 2, no. 12A (2014): 1-7. doi: 10.12691/education-2-12A-1.

\section{Introduction}

The greatest resource and strength in Indian schools is our teachers. They account for the vast majority of expenditure in school education and have the greatest impact on student learning, far outweighing the impact of any other education programme or policy. The Code of Ethics of the teacher Education Profession indicates the aspiration of all educators and provides standards by which to judge conduct. The desire for the respect and confidence of one's colleagues, of students, of parents, and of the members of the community provides the incentive to attain and maintain the highest possible degree of ethical conduct.

Teachers are the greatest assets of any education system. They stand in the interface of the transmission of knowledge, skills and values. They are accepted as the backbone of education system. Teacher quality is therefore crucial and has been globally accepted to be significantly associated with the quality of education in general and students' learning outcomes in particular. The Education Commission (1964-66) of India accepted this influence of teachers in powerful words, "No system can rise above the status of its teacher..." Similar sentiments have been expressed by the Delors report (1996), and UNESCO report on Teacher and Educational Quality: Monitoring Global Needs for 2015 (2006) [1].

The organisation of teacher education in any system can be visualized at two levels. At the systemic level, the positioning of teacher education determines its nature. Teaching is a multifaceted and specialized activity, and therefore, is housed in single purpose institutions in majority of countries around the world. The second level is the structure of curriculum i.e. what should be taught and how it should be taught. At this level Schulman's (1987) conceptualization of teacher's knowledge provides the base of teacher education curriculum structure [2]. According to Schulman [2] a teacher should possess subject content knowledge, general pedagogical knowledge, and the knowledge of educational contexts and goals; and should be able to use this knowledge creatively to deal with ever changing classroom situations. If we analyse teacher education systems in different countries from this perspective we will find majority of teacher education reform efforts centred on reforming the knowledge base of teachers, and similarities can be observed in teacher education curriculum across various societies. However, the problems and methods to resolve these vary and are context specific. 
One purpose of our research was to develop an understanding of teachers' perspectives of teacher-student emotional involvement and emotional interactions in the classroom. The literature on the ethic of care and the emotional dimensions of teaching provided much of the framework of our research [3,4]. In this study, one of the major themes that emerged from initial analysis of our interviews with students and teachers was their struggle with relationship boundaries as part of their emotional interactions with Teacher's/students.

In this connection we found that, Teachers share a significant responsibility in preparing young people to lead successful and productive lives. The National Professional Standards for Teachers (the Standards) reflect and build on national and international evidence that a teacher's effectiveness has a powerful impact on students, with broad consensus that teacher quality is the single most important in-school which influencing student achievement. Effective teachers can be a source of inspiration and, equally importantly, provide a dependable and consistent influence on young people as they make choices about further education, work and life. Internationally and locally, education systems are developing professional standards for teachers to attract, develop, recognize and retain quality teachers. So there is a need to get understanding of perceptions and attitudes of the both teachers and students regarding their attitudes and expectations on teacher-student relationship which was the major thirst of the study.

\section{Conceptual Framework}

\subsection{Ethical Issues of a teacher: an Overview}

In my mind now students are the God and teachers are the Priest within the temple (School). So it is crystal clear that both are made for each other within the system without one other will be value less. So before highlighting the relationship I want to highlight the concrete presence of teacher within the system "A school without a teacher is just like a body without soul, a skeleton without flesh and blood, a shadow without substance”.

The ethical dimensions are considered to be important in our educational system and are present in several legislative documents, both with regard to the education of pupils and to teacher education, and regarded as important for professional performance. Take, for instance, the Education Act, where the ethical issues, associated with social, spiritual, moral and civic values are implicit as both organizational principles and objects of elementary and secondary education. Also, as far as teacher education is concerned, in the National Council of Teacher Education (NCTE) and National Council of Educational Research and Training (NCERT) which approves the legal regime of professional skills for teaching at pre-schools', elementary and secondary levels, the following emerge as components of basic training: "cultural, social and ethical education covering preparation for the non-disciplinary curriculum areas and reflection on the ethical and civic dimensions of the teaching profession”.

\subsection{Review of Related Literature}

The pre-service teacher preparation programmes remain the important determinant of how teachers learn and succeed in the dynamic circumstances of real classroom and school. India has made concentrated efforts to modify and modernize teacher education curricula to suit the requirements of contemporary educational needs of the society and instill greater professionalism and commitment in practicing teachers through pre-service and continuous in-service teacher education programmes. The National Policy of Education (NPE, 1986) reflects this commitment by considering pre-service and in-service teacher education as a continuous process and two ends of a continuum. An analysis of the recommendations of various commissions, committees and the education policy of India reveals the efforts of policy planners to bring qualitative improvement in teacher education system along with quantitative expansion of the facilities. Efforts have been made to make teacher education curricula responsive to the contextual needs of emerging society, and break the isolation of teacher education institutions. Yashpal Committee (1993), appointed to analyse the academic burden on students and unsatisfactory quality of learning expressed concern over the poor quality of teacher preparation programmes in the country which leads to unsatisfactory quality of learning in schools. This committee also suggested restructuring of the course content of teacher education programmes to ensure its relevance to the changing needs of school education, longer duration of training, emphasis on self-learning and independent thinking and making whole teacher education programme more practicum-oriented. Hallak and Poisson, [5], The major cause of ethical deterioration in education system is rapidly spreading corruption. There was a time when corruption was only in Government offices, private institutions, police stations etc. But, now a day's corruption has spread its roots in education system also. Corruption in the education sector can be defined as "the systematic use of public office for private benefit, whose impact is significant on the availability and quality of educational goods and services as a consequence on access, quality or equity in education”. Singh and Purohit, (2011), Privatization of educational institutes is another major cause for the declining ethical values in education system. Privatization of education has emerged in several forms in the recent decade in India. Government allowed to opens self-financing private institutions with recognition, which may be termed as commercial private education institutions [6,7]. Garg and Kaur, (2012), With the mushrooming of these private institutes in the modern era, the education has acquired the status of a marketable commodity, where educational institutes are the traders and students are the customers [8]. Bray (2003), Teacher absenteeism is one of the most serious causes of ethical declining of education. It greatly reduces the overall effectiveness of the school, diminishes pupils' achievements, damages the school's reputation, and induces pupil absenteeism [9]. Bala Harish, (2011) However the present curriculum makes them perfect money makers, the best politicians, the well- known doctors, the skilful engineers, the greatest musicians, the marvellous actors but fails to make then realize a bit to their identity as human beings[10]. Raina (1999) "teacher training programmes in India have remained procrustean, offering the same menu to all without slightest regard for 
varying cultural and physical settings, They remained unresponsive to vast cultural, linguistic, regional and geographical diversity”. Beyer, (1997) [11]; Caetano, (1997) [12], (1998) [13]; Woods et al., (1997) [14] In the sense of giving voice to teachers, their real dilemmas and tensions, taken here as a broad concept to include difficulties, problems and dilemmas and subjectively presented by subjects in professional situations, are expected to serve as a vehicle, among a number of other strategies. Thus, they will form the basis of subjective experiences of conflict, discrepancy, questioning and uncertainty which push people to opposite directions, with a personal and emotional dimension associated with restlessness, impatience and even anxiety, resulting in a decision process which can be reflective to varying degrees and puts a variety of perspectives, feelings, actions, interactions and their consequences into confrontation, as well as elements of a contextual nature. Hence, the concept points to a dialogic perspective through which tensions are equated, closely examined and sometimes attenuated or overcome, ranging in intensity, being problematic or difficult to varying degrees, creative and strategic or even limited by situational constraints [15].

\subsection{Rationale of the Study}

Teachers are the greatest assets of any education system. They stand in the interface of the transmission of knowledge, skills and values. They are accepted as the backbone of education system. Teacher quality is therefore crucial and has been globally accepted to be significantly associated with the quality of education in general and students' learning outcomes in particular. So now the teaching profession is vested by the public with a trust and responsibility requiring the highest ideals of professional service. The aim of such training is, on the one hand, to help teachers in the ethical education of their pupils, on the other hand to support them in the performance of a high ethical profession.

In the belief that the quality of the services of the teaching profession directly influences the nation and its citizens, the educator shall exert every effort to raise professional standards, to promote a climate that encourages the exercise of professional judgement, to achieve conditions that attract persons worthy of the trust to careers in education, and to assist in preventing the practice of the profession by unqualified persons. With the above fruitful discussion now the serious question in front of us who shocked us when we are analyzing the current teacher education status like: What training implications stem from the conceptions of teachers regarding ethics and the way it is learned? Which ethical concepts emerge? Is it possible for a deontological code of the teaching profession and training to be articulated in the ethical regulation of the profession? What is the position of teachers in terms of ethical training? To what extent are they satisfied with the training received? These are some of the questions we have tried to answer in our next point. Therefore, in this paper an attempt has been made to analyze the present status of educational environment in teacher education field and the teacher taught relationship, along with tried to get answers of above and below praiseworthy questions.

\subsection{Research Questions}

The study addressed to answer the following questions.

1. What are the current ethical problems in the field of teacher education?

2. How does teachers/trainees experiences ethical dilemmas terms of relationship boundaries in practical field?

3. What is the perception of teachers on their curriculum with reference to ethical education?

\subsection{Objectives of the Study}

1. To highlight current ethical issues in the field of teacher Education.

2. To document possible ethical boundaries perceived by teacher trainees in teacher institutions.

3. To explore pre-service and in-service teachers' perceptions on ethical education.

\subsection{Methods}

We approached this study from a phenomenological perspective. Using a phenomenological perspective allows us to investigate new, unanticipated themes and understandings to emerge by exploring a small number of cases in great depth and rich detail. We bracketed, or set aside as much as possible, our own experiences, assumptions, and beliefs about emotions and teacherstudent relationships to transcend our perceptions of the nature of the phenomenon. Our ultimate goal in bracketing was to look at the data with fresh eyes. Using a phenomenological perspective also facilitated our attempt to answer the more specific questions we asked of our data: how do teachers define their relationship boundaries in dealing with emotions in the classroom? With what types of issues do teachers typically have difficulty? How do teachers make decisions regarding relationship boundaries? Etc.

\subsection{Participants}

One hundred in-service teachers from both high schools and primary schools from Indira Gandhi National Open University (IGNOU) and hundred pre-service teacher's trainee from am Chandra Institute of Education Technology (RCIT) B. Ed College. So the sample of the study comprised two hundred teacher trainees.

\subsection{Tools}

The following tool is used in collection of data for this study.

1. Interview schedule for obtaining direct information from both in-service as well as pre-service trainees.

For Example: Interview questions included: (1) tell me how you went about building rapport with your students? (2) What types of things do you share with your students? (3) What do you think that "getting too involved with students" means? (4) How do teachers talk about teacherstudent emotional involvement or "emotional distance" from students? (5) Do you think you are giving justification to your profession? (5) Have you ever felt that it is the best noble profession and you are fit for it? (6) Do you think present teacher education curriculum provides proper ethical education? (7) How political 
interferences destroying the teacher education in India? and (8) How privatization and other factors have bad impacts on this noble profession? etc.

\subsection{Data Analysis}

We adapted Strauss and Corbin's (1999) open coding as a technique to analyze participants' statements relevant to teacher-student relationships and emotional interactions in the classroom. Each transcript was simultaneously coded by all the researchers [16].

We then compared and discussed our decisions among the research group. Several passes were made over the transcripts, and the development of categories was an ongoing, iterative process, based on common codes across transcripts. We re-evaluated and refined both the codes and the categories to mirror participants' descriptions of teacher-student relationships. Then we began looking for patterns in the data across all participants. We allowed the boundary themes to emerge inductively from the data, but subsequently went through a second process of comparing the data deductively to the relevant literature on professional boundaries.

We report our findings with quotes from our participants, meant to capture the essence of participant beliefs about and experiences of teacher-student relationships, the emotional involvement inherent in those relationships, and the boundaries teachers established in their relationships with students.

\section{Discussion}

\subsection{Current Ethical Issues}

\subsubsection{Corruption in Teacher Education}

The major cause of ethical deterioration in education system is rapidly spreading corruption. There was a time when corruption was only in Government offices, private institutions, police stations etc. But, now a day's corruption has spread its roots in education system also. Corruption in the education sector can be defined as "the systematic use of public office for private benefit, whose impact is significant on the availability and quality of educational goods and services. Corruption in education can include bribes and illegal fees for admission and examination; academic fraud; withholding teacher salaries; preferential promotion and placement; charging students for "tutoring" sessions to cover the curriculum needed to pass mandatory examinations which should have been taught in the classroom; and infrastructural work.

\subsection{Privatization of Educational Institutes}

Privatization of education has emerged in several forms in the recent decade in India. Government allowed to opens self-financing private teacher institutions with recognition, which may be termed as commercial private teacher education institutions. With the mushrooming of these private institutes in the modern era, the education has acquired the status of a marketable commodity, where educational institutes are the traders and students are the customers. These institutions started courses like B.Ed, D.Ed, M.Ed, BP.Ed and many more without basic infrastructure and qualified teaching faculties. They are appointing those teachers that are low salaried and far away from the standards. In this environment, teachers do not have any Job security, so that they always do as management desire and they are morally down in the dumps.

\subsection{Political Interference}

The political interference is largely responsible for misuse of human resource management in education. Political parties often use many teachers as their party workers and these teachers also participate willingly in politics. Those teachers who are very close to political leaders have records of misconduct and unethical behaviour such as irregularity in class teaching, becoming absent from the school without taking leave. Political leaders, high-level bureaucrats and members of the teacher unions also attempt to influence decision-making regarding the recruitment and transfer of teachers. Favouritism, nepotism and bribes are major types of misconduct in teacher's appointment, posting and transfer. So the moral and ethical commitment of teachers has gradually decreased over the years due to political interference.

\subsection{Ethics of Care in Teacher-Student Relationship}

The teacher should take a pledge to follow the code of ethics which may bring credit to the entire profession. The basic concepts of care mentioned in the literature review are evident in the actions of our participants. In establishing rapport with the students, one can say he wants the students to know 'we' are going to have respect each other and be open and accepting to other's points of view. I think the main issue is trust. Then one can believe that the positive classroom environment is the product of taking the time to talk with the students in her classes about things in which they are interested, whether it is a current event or an ethical dilemma.

\subsection{Un-Fair Assessments}

Course assessments of student learning must be objective, valid, fair, but at present there are many factors that may affect fairness in grading. Teachers should also avoid letting unrelated factors or personal biases which affect their grading of student assessments. It is now a major problem in the field of teacher education many institutions and universities are there, where assessment is doing with taking illegal money from the upcoming teachers. Also practical marks given to students after exploiting them in different ways, which lead to frustration in case of teacher, trainees etc. and the cause of emotional problem.

\subsection{Teachers' Absenteeism}

Teachers are the role models of students and in most rural communities, they are the most educated and respected personality. Teachers are the spreader of knowledge who helps developing pupils' understanding, attitudes, skills, learning, and core values [17]. While simultaneously those teachers are mostly absent from 
classes providing negative role models for students. Education is now in the grasp of corruption because of high rate of teacher absenteeism. The UNESCO's International Institute of Educational Planning study on corruption in education state that there is $25 \%$ teacher absenteeism in India which is among the highest in the world. In Bihar two of every five teachers were reported absent, the figure in UP was reported to be one-third of the total teachers. Ghost Teacher does not just affect quality of education but it is also a huge drain on resources resulting in the wastage of $22.5 \%$ of education funds of India. Teacher absenteeism is one of the most serious causes of ethical declining of education. It greatly reduces the overall effectiveness of the school, diminishes pupils' achievements, damages the school's reputation, and induces pupil absenteeism.

\subsection{Boundaries in Teacher-student Relationships}

As our participants shared stories about their relationships with students, their ideas about relationship boundaries emerged. We present the boundaries, derived both inductively and deductively from our data, with different categories however, Communication, emotions, and relationship boundaries were the most salient in the interview.

\section{Communication Boundaries}

Communication boundaries seemed to centre most often on issues of self-disclosure to students. According to the one participant "I think you really should share as much as you can with the kids so they can see you as a human being, and they can see how you react to frustration." The act of modeling emotional regulation for his students served as the impetus for self-disclosure in this instance.

\section{Cultural Boundaries}

Self-disclosure can also be construed as a vehicle for cultural sharing. Most of our participants stated that their school districts were transitioning to a higher level of diversity as students of various ethnic backgrounds moved into their areas. Donna's willingness to discuss her personal background and celebration of family holidays with her students suggests the importance of individual openness to different cultural backgrounds in the classroom. Helping students understand the various influences on not only the teachers, but also on their peers, may lead to better understanding, communication, and cooperation in the classroom as students respect cultural differences.

\section{Emotional Boundaries}

There must be one protocol in between teacher and teacher trainee on like; Emotional regulation, appropriate levels of emotion shared in the classroom, and comfort levels with others' emotions were among the responses we encountered. What are sometimes perceived as "unpleasant" emotions: anger, frustration, and even hate were mentioned as emotions that should be masked or expressed with care. Participants also talked about boundaries of emotional intensity. There are levels of emotions you shouldn't share. And what's appropriate for one child might totally be inappropriate for another."

\section{Relationship Boundaries}

The teacher-student relationships have received the most press and notoriety not only in India but also in the world. No doubt Stories in the news of intimate teacherstudent relationships have decreased over the last several years. I think if it got to the point where the teacher's emotions depended on a student that could be pretty dangerous. So you have to care and be genuine but at the same time you can't let yourself get carried away. You have to have stability of your own personal life and not put that into a student. That would be where you would be crossing the line and getting too involved.

\subsection{Missed Ethical Education in Current Teacher Training Curriculum}

A major problem facing teacher education programme in India is the un-relatedness of the theoretical discourses at the training college and classroom realities of schools. The duration of teacher preparation has also been the cause of concern. The question of longer duration for professional preparation of teachers has once again missed the attention of course developers of the National Council of Teacher Education (NCTE). Therefore, though the framework of teacher education (2009) recommends two years of teacher preparation programme, but still now the course structure developed by National Council of Teacher Education (NCTE) for B.Ed course is for one year only. This creates apprehension about the intent to bring any real change in the teacher education system.

In ancient India, the Vedas, the Upanishads, the epics manifested and upheld the values of Indian society. Imparting value education was the main aim of the teachers of the ancient age. At present value education is not started at schools nor taught at teacher institutions in India. Although value education is included in the primary education curriculum but at the adolescent or adult stage, which are the most sensitive stages to build the character of the youth, the curriculum finds no space to value education. However the present curriculum is fit to make them perfect money makers, the best politicians, the wellknown doctors, the skilful engineers, the greatest musicians, the marvellous actors but fails to make then realize a bit to their identity as human beings.

The National Curriculum Framework (NCF 2005) focuses on pedagogical and curricular approach which behests a lot of responsibility and ownership on the part of teachers such as use of culture specific context, examples, folk lores, folk stories, and experiences of individual learners in the classroom. Mere change in teacher curriculum does not guarantee its successful implementation. Therefore, they themselves need de learning of conventional approaches and re learning of emerging approaches and pedagogical content knowledge to act as facilitators of learning.

Teacher education curriculum is expected to develop dispositions among teachers to discharge their duties effectively, which is sensitive to the needs of field applications but the existing curriculum, however fails miserably to bring to the surface this applied aspect of various philosophical, sociological and psychological 
ideas, and hence the whole teacher education programme remains theoretical and divorced from the grass root realities of classrooms. It fails to develop an understanding among the students about education as independent discipline in itself and it's interring linkages with various cognate disciplines.

\subsection{Educational Implications / Recommendations}

1. One programme is needed where the teacher takes responsibility for his/her ethical action and the ethical development of his/her pupils. On equating dilemmas and tensions as a general starting point and analysis themes for training, we can direct the task of their examination by appealing for reflective writing on ethical, practical and contextual dimensions diversified reading, complex novelizations, debates and role-playing.

2. One equating dilemmas and tensions as a general starting point analysis theme for training, we can direct the task of their examination by appealing for reflective writing on ethical, practical and contextual dimensions diversified reading, complex novelization, debates and role-playing.

3. It is also important to look for a creative unit that will overcome the conflict and bring about integration. Where, for example, new values or other solutions are appealed for, where values are not in contradiction; or even by maintaining contradiction, developing images which reconcile the apparently irreconcilable.

4. It also tries to address the criticism regarding the unrelatedness of theoretical discourses of teacher education institutions to the classroom realities by incorporating the socio-cultural contexts of education, giving more weight age to the field experience of student teachers in all courses through practicum, visits to innovative centres of pedagogy and learning, classroom based research, longer duration of internship i.e minimum duration of six to ten weeks for a two year programme (four days per week), and 15-20 weeks for a four year programme, including an initial phase of one week for observing a regular classroom with a regular teacher.

5. The duration of teacher preparation has also been the cause of concern. None of the policy documents and teacher education curriculum frameworks contested over the need of longer duration of teacher education programme for ensuring professionalism in prospective teachers and the general consensus for the duration of B.Ed course has been at least of two years, yet the ground realities never changed. The question of longer duration for professional preparation of teachers has once again missed the attention of course developers of the NCTE. Therefore, though the framework of teacher education (2009) recommends two years of teacher preparation programme, the course structure developed by NCTE for B.Ed course is for one year only. This creates apprehension about the intent of those at the helm of affair to withstand pressures from different quarters and break away from the traditional path to bring any real change in the teacher education system.

6. It is also envisages a two year teacher preparation programme along with the four year integrated teacher education courses. It is felt that longer duration of teacher preparation will provide enough time and opportunity for self- study, reflection and engagement with teachers, students, classrooms and pedagogic activities that is essential for developing professionalism in teachers.

7. Flexibility within the framework of acceptable national goals and values. The framework suggested that 'flexibility is urgently required not only to break the barriers between the stage wise teacher education programmes, but also, between different disciplines'. Flexibility for relevance, mobility and continuing education was emphasized.

8. Interdisciplinary and integrated approach in teacher education curriculum should be so designed that integration among theory courses takes place, and this integrated pedagogical understanding flows into the skill dominated areas of methodology of teaching various subjects as well as into the attitude-building areas of work experience, health, physical and recreational education, along with social service.

9. In India Should Task-oriented teacher education. Teacher education must be treated as an "exercise of training a teacher for handling a variety of tasks inside and outside the classroom.” Also Reform in practice teaching. The framework suggested that student teachers should be put through a series of simulating, microteaching situations before being pushed into actual classrooms.

10. It calls for reorientation of teacher educators in the emerging pedagogies who are trained in conventional methods and are used to conventional pedagogies. The problem is further aggravated form the lack of experiences of majority of teacher educators in teaching at school level. Nothing can change significantly in the preparation of teachers if the corresponding changes are visualised in the preparation of teacher educators. Therefore, they themselves need de learning of conventional approaches and re learning of emerging approaches and pedagogical content knowledge to act as facilitators of learning.

\section{Conclusion}

Teachers are the greatest assets of any education system. They stand in the interface of the transmission of knowledge, skills and values. They are accepted as the backbone of education system. Teacher quality is therefore crucial and has been globally accepted to be significantly associated with the quality of education in general and students' learning outcomes in particular. It is high time to identify the major causes of declining ethical values in Indian teacher education system. The only way to arrest this decline is in providing value-orientation in Indian teacher education field. In India, it is necessary to increase ethical values, philosophical thinking, study, research and moral development in education system. 


\section{References}

[1] Delors Jacques. Learning: The Treasure Within. Report of the international Commission on Education for Twenty-first century. UNESCO. Paris. 1996.

[2] Schulman, I.S. Knowledge and teaching: Foundations of new reforms. Harvard Educational Review, 57 (1), pp 4-14, 1987.

[3] Noddings, N. Caring: A feminine approach to ethics and moral education. Berkley, CA: University of California Press, 1984.

[4] Noddings, N. Teaching themes of caring. Education Digest, 61 (3), 24-28. 1995.

[5] Hallak, J. and Poisson, M. Corrupt schools, corrupt universities: What can be done? Published by International Institute for Educational Planning, UNESCO, 2007, www.unesco.org/iiep

[6] Abhinav Singh and Bharathi Purohit, Fracas over Privatisation, Quality Assurance and Corruption in Indian higher education, Journal of Education and Practice, Vol. 2, No 11\&12, 2011, www.iiste.org

[7] Abhinav Singh and Bharathi Purohit, Reconsidering privatisation for corruption free administration in Indian higher education, Education Research Journal, Vol. 1 (7): 128-134, 2011, http://www.resjournals.com/ERJ

[8] Kanchan Garg and Kamaljeet Kaur, Declining of Ethical Standard in Higher Education System in India presented in Cambridge Business \& Economics Conference, Cambridge, UK, 2012.
[9] Bray, M. Adverse Effects of Private Supplementary Tutoring: Dimensions, Implications and Government Responses. Paris: IIEP-UNESCO, 2003.

[10] Bala Harish, Challenges of Higher Education in 21st Century, Journal of Education and Practice, Vol 2, No 6, pp 78-81, 2011, www.iiste.org

[11] Beyer, L. The moral contours of teacher education. Journal of Teacher Education, 48, 4, pp. 245-254, 1997.

[12] Caetano, A. P. Dilemmas dos professors. In M. T. Estrela (org.), Viver e construir a profissão docente. Porto: Porto Editora, pp. 191-221, 1997.

[13] Caetano, A. P. Dilemmas dos professores, decisão e complexidade de pensamento. Revista de Educação, VII, 1, pp. 75-90, 1998.

[14] Woods, P.; Jeffrey, B.; Troman, G. \& Boyle, M. Restructuring schools, reconstructing teachers. Buckingham: Open University Press 1997.

[15] Caetano, A. P. Tensões na investigação-acção e processos de mudança. Actas do $5^{\circ}$ Colóquio da Sociedade Portuguesa de Ciências da Educação de 2000. Porto: Sociedade Portuguesa de Ciências da Educação, 2002.

[16] Strauss, A.,\& Corbin, J. Grounded theory methodology: An overview. Ina. Bryman, \& R. G. Burgess (Eds.), Qualitative Research. London: Sage Publications, Inc. 1999.

[17] Patrinos, H. A. and Ruthkagia, Maximizing the Performance of Education Systems The Case of Teacher Absenteeism published in The Many Faces of Corruption 63-87, 2007. 